E-JURNAL EKONOMI DAN BISNIS UNIVERSITAS UDAYANA
Available online at https://ojs.unud.ac.id/index.php/EEB/index
Vol. 10 No. 04, April 2021, pages: 191-200
e-ISSN: 2337-3067

\title{
PENGUATAN DAYA SAING DAERAH MELALUI KERJASAMA TERAS UTARA SULAWESI INDONESIA
}

Fahrudin Zain Olilingo ${ }^{1}$ I Kadek Satria Arsana ${ }^{2}$

Article history:

Submitted: 28 September 2020

Revised: 22 Desember 2020

Accepted: 17 Februari 2021

\section{Keywords:}

Cooperation;

Strengthening;

Competitiveness;
Kata Kunci:

Kerjasama;

Penguatan;

Daya Saing;

\section{Koresponding:}

Sekolah Tinggi Ilmu

Administrasi Bina Taruna,

Indonesia

Email:

satriaarsana28@gmail.com

\section{Abstract}

The research approach used is qualitatively descriptive narrative. The results showed that in improving regional competitiveness through cooperation between regions there are several efforts that have an important role in improving regional competitiveness through regional cooperation, namely maintaining a joint commitment in maintaining the momentum of cooperation, increasing the role of the community in northnorth cooperation, improving the business climate and regional business climate, improving regional infrastructure, increasing the competitiveness of regional superior export products, improving the quality of regional human resources and creating a more conducive regional employment climate. Strengthening the competitiveness of each region is very important to create the competitiveness of the north-north cooperation area that will be built with the commitment of the principle of mutual cooperation, mutual need and mutual strengthening. This paper illustrates the factual condition of north-north cooperation that will be an important point in developing regional cooperation in the future..

Abstrak
Pendekatan penelitian yang digunakan adalah kualitatif deskriptif
naratif. Hasil penelitian menunjukkan bahwa dalam meningkatkan daya
saing daerah melalui kerjasama antar daerah terdapat beberapa upaya yang
memiliki peran penting dalam meningkatkan daya saing daerah melalui
kerjasama daerah yakni menjaga komitmen bersama dalam
mempertahankan momentum kerjasama, peningkatan peran masyarakat
dalam kerjasama utara-utara, perbaikan iklim usaha dan iklim usaha daerah,
peningkatan infrastruktur daerah, peningkatan daya saing produk ekspor
unggulan daerah, peningkatan kualitas sumber daya manusia daerah dan
penciptaan iklim ketenagakerjaan daerah yang lebih kondusif. Penguatan
daya saing masing-masing daerah sangat penting untuk menciptakan daya
saing kawasan kerjasama utara-utara yang akan dibangun dengan komitmen
prinsip kerjasama saling mendukung, saling membutuhkan dan saling
memperkuat. Tulisan ini menggambarkan kondisi faktual kerjasama utara-
utara yang akan menjadi titik penting dalam mengembangkan kerjasama
daerah dimasa yang akan datang.

Universitas Negeri Gorontalo, Indonesia ${ }^{1}$

Email: fzo@ung.ac.id ${ }^{1}$ 


\section{PENDAHULUAN}

Pelaksanaan pembangunan dapat dilakukan dengan berbagai cara, salah satunya adalah dengan membentuk sebuah kerjasama yang melibatkan beberapa daerah, wilayah maupun negara untuk mencapai tujuan dan kepentingan bersama dengan berasaskan kepentingan masyarakat (Utomo, 2006), (Bagaskara \& Pattipelohy, 2018). Menurut Teori Maxis yang banyak di pakai oleh beberapa ahli pembangunan bahwasanya, pembangunan wilayah dapat dilihat dari berbagai sektor dan kerjasama regional adalah satu cara yang lazim dilakukan untuk memajukan wilayahnya (Tilzey, 2017). Bentuk kerjasama energi dan teknologi yang dilakukan oleh Rusia dan beberapa negara di Asia timur (Saneev et al., 2018), memberikan dampak yang positif pada perubahan energi dan teknologi untuk menghadapi tantangan global. Kerjasama Rusia dan Korea Utara yang terjalin banyak memberikan manfaat dalam mengembangkan ekonomi wilayah melalui perdagangan, terbukti di tahun 2013 Rusia memiliki kontribusi perdagangan ke Korea Utara (ASEAN) hanya 1\% namun di tahun 2020 volumenya meningkat, (Zakharova, 2016), (Martynova, 2014). Selain itu, bentuk kerjasama ASEAN+3 negara dibidang kerjasama keuangan negara sukses memfasilitasi negara terhindar dari keterpurukan dan pada akhirnya dapat meningkatkan pertumbuhan ekonomi (Park, 2017). Beberapa isu penting dalam sebuah kerjasama regional adalah menentukan faktor eksogen dan endogen yang dimiliki oleh setiap daerah menjadi sebuah proses aplikatif untuk mendukung pertumbuhan dan perkembangan regional yang berkelanjutan (Basco, 2015).

Salah satu bentuk kerjasama regional yang digagas oleh Universitas Negeri Gorontalo adalah kerjasama 3 (tiga) daerah di bagian utara Sulawesi yang meliputi 4 kabupaten dalam 3 provinsi, hal ini menjadi menarik dan merupakan sebuah langkah penting dan menjadi sesuatu yang unik karena baru pertama kali di Indonesia suatu kerjasama yang melibatkan 4 daerah kabupaten dalam 3 provinsi yang berbeda yaitu Kabupaten Gorontalo Utara dan Bone Bolango Provinsi Gorontalo, Kabupaten Buol Provinsi Sulawesi Tengah dan Kabupaten Bolaang Mongondow Utara Provinsi Sulawesi Utara dan melibatkan Universitas Negeri Gorontalo sebagai fasilitator.

Dalam sebuah penelitian (Sun, 2016) mengungkapkan bahwa sejak tahun 2000 terbentuk sebuah kerjasama jaringan antara beberapa universitas dan beberapa perusahaan pada daerah segitiga antara sungai Delta Yangtze, Delta Mutiara dan Rim Bohai, kerjasama ini terjadi tanpa ada ikatan yang terjadi karena adanya hubungan komplementer yang didasarkan pada relevansi perkembangan daerah tersebut. Bentuk kerjasama utara-utara adalah salah satu wadah dan perwujudan dari persamaan lokasi dan tujuan yang ingin dicapai oleh beberapa kepala daerah agar ketiga daerah ini dapat menjadi kawasan yang lebih maju, tumbuh, berkembang dan dapat menjadi prime mover bagi daerah sekitarnya.

Kerjasama Regional Utara-Utara yang terbentuk tanggal 17 September 2014 telah mengalami pertambahan anggota dengan masuknya Kabupaten Bone Bolango Provinsi Gorontalo yang disepakati dan ditandatangani oleh para Bupati Kawasan Kerjasama Utara-Utara di Den Haag Belanda tanggal 10 Mei 2017 sekaligus menandai perubahan nomenklatur kelembagaan kerjasama utara-utara dari yang sebelumnya Sekretariat Bersama menjadi Badan Kerjasama Utara-Utara yang akan diketuai Bupati anggota organisasi kawasan utara-utara secara bergilir. Kesepakatan dari ke empat kabupaten dimaksud menandai munculnya spirit membangun dari keempat daerah untuk bersama-sama saling mengisi dalam menggerakkan ekonomi untuk kepentingan bersama dalam mencapai kesejahteraan masyarakatnya (Mudrajad, 1997). Spirit dimaksud menjadi titik awal dalam merencanakan secara bersama pembangunan yang saling mendukung antara satu dan lain sehingga kawasan ini memiliki daya saing dan akhirnya akan menciptakan sumber pertumbuhan baru di 
kawasan timur Indonesia. Oleh karena itu, penelitian yang dilakukan ini bertujuan untuk menganalisis upaya yang dapat dilakukan dalam meningkatkan daya saing daerah melalui kerjasama daerah.

\section{METODE PENELITIAN}

Penulisan makalah ini berdasarkan atas penelitian yang penulis pernah lakukan di daerah ini sebanyak dua kali serta pengamatan yang berulang (Fachrudin Zain Olilingo, 2014) sebagai yang merintis terbentuknya kerjasama ini serta menjalaninya bersama-sama dengan pemerintahan pada ke empat daerah Badan Kerjasama Utara-Utara serta para ilmuan dari Universitas Negeri Gorontalo. Pendekatan penelitian yang digunakan dalam penelitian ini adalah penelitian kualitatif. Penggambaran dan analisis data dilakukan secara deskriptif naratif (Agostinho, 2005), (Golafshani, 2003) untuk mendeskripsikan dan menemukan suatu fenomena yang memiliki karakter unik dalam implementasi karena semata-mata ingin menunjukkan eksistensi kawasan kerjasama utara-utara serta prospek yang diinginkan untuk menggapai cita-cita bersama dari para anggotanya. Sumber data yang digunakan dalam penelitian ini adalah data primer diperoleh langsung melalui wawancara kepada pemangku kebijakan pada masing-masing daerah penelitian dan data sekunder diperoleh dari berbagai literatur yang relevan dengan penelitian. Namun terdapat kendala yang dihadapi dalam penulisan karena kurangnya data pendukung seperti realisasi investasi, realisasi perdagangan baik perdagangan antar pulau maupun internasional. Hal ini terkait pencatatan perdagangan masih kurang terintegrasi antara daerah dan provinsi apalagi masing-masing daerah kerjasama utara-utara bukan merupakan pelabuhan ekspor langsung dalam perdagangan internasional.

\section{HASIL DAN PEMBAHASAN}

Keragaan Ekonomi Kawasan Kerjasama Utara-Utara; Pentingnya keragaan ekonomi masing-masing kabupaten adalah untuk mengetahui terminal point masing-masing daerah dalam memulai kerjasama baik menyangkut potensi, kinerja ekonomi serta daya dukung lainnya dalam melakukan aktifitas kerjasama. Tabel 1 menjelaskan luas wilayah dan jumlah penduduk serta kepadatan penduduk 4 kabupaten kerjasama utara-utara.

Tabel 1.

Indikator Makro Ekonomi 4 daerah Kerjasama Utara-Utara Tahun 2018

\begin{tabular}{clccc}
\hline No. & \multicolumn{1}{c}{ Keterangan } & $\begin{array}{c}\text { Luas Wilayah } \\
\left(\mathbf{K M}^{2}\right)\end{array}$ & $\begin{array}{c}\text { Penduduk } \\
(\text { Jiwa })\end{array}$ & $\begin{array}{c}\text { Kepadatan } \\
\text { Penduduk }\end{array}$ \\
\hline 1 & Buol & $4.043,57$ & 158.790 & 39,27 \\
2 & Bone Bolango & $1.984,31$ & 159.194 & 83 \\
3 & Bolaang Mongondow & $1.856,86$ & 79.366 & 42,74 \\
& Utara & $1.777,22$ & 114.036 & 64,17 \\
\hline & Gorontalo Utara & $9.656,96$ & 511.386 & 57,30 \\
\hline
\end{tabular}

Sumber: BPS Buol, Bone Bolango, Bolaang Mongondow Utara dan Gorontalo Utara 2019

Daerah yang menempati urutan pertama dari luas wilayah di Kawasan Kerjasama UtaraUtara adalah Kabupaten Buol dengan luas 4.043,57 $\mathrm{km}^{2}$ atau sekitar 41,87 \% dari luas daerah kawasan kerjasama. Walaupun terluas tapi penduduknya masih kurang dengan tingkat kepadatan penduduk 39 orang per $\mathrm{km}^{2}$ dengan jumlah penduduk sebanyak 158.790 orang atau $31,84 \%$ dari keseluruhan 
jumlah penduduk di wilayah kawasan kerjasama. Kabupaten Buol dihuni oleh penduduk multi etnis baik dari suku Bugis, Makassar, Kaili, Jawa bahkan juga dari Gorontalo. Secara historis daerah ini pernah menjadi bagian dari Kerajaan Gorontalo sebelum Indonesia merdeka sebagai salah satu keresidenan Gorontalo oleh karena itu tidak mengherankan kalau kultur dan budayanya memiliki kemiripan dengan daerah Gorontalo termasuk kuliner tradisonal. Urutan kedua dari luas wilayah kerjasama utara-utara adalah Kabupaten Bone Bolango dengan luas 1.984,31 km ${ }^{2}$ dan tingkat kepadatan penduduk 83 orang per $\mathrm{km}^{2}$. Daerah ini terpadat penduduknya di wilayah kawasan kerjasama karena mungkin sangat dekat dengan ibu kota Provinsi Gorontalo atau sebagai wilayah penyanggah Kota Gorontalo. Kabupaten Bone Bolango nanti tahun 2017 memperkuat kerjasama utara-utara dengan ditandatanganinya nota kesepahaman tanggal 10 Mei 2017 di Den Haag Belanda sekaligus menandai perubahan nomenklatur Sekretariat Kerjasama Utara-utara menjadi Badan Kerjasama Utara-Utara.

Walaupun masih terhitung baru, namun kiprahnya dalam kerjasama utara-utara sangat baik terbukti Bupati Bone Bolango terpilih sebagai Ketua kawasan kerjasama utara-utara tahun 2017-2018. Kabupaten Bolaang Mongondow Utara menempati urutan ketiga dari luas wilayah kawasan kerjasama dengan tingkat kepadatan penduduk 43 orang per $\mathrm{km}^{2}$. Daerah ini berbatasan dengan Kabupaten Gorontalo Utara dan merupakan daerah yang dilalui apabila bepergian dengan darat ke Manado Provinsi Sulawesi Utara. Penduduk Kabupaten Bolaang Mongondow Utara juga memiliki kedekatan kultural dan historis dengan Gorontalo sehingga sangat pantas untuk melakukan kerjasama dalam bingkai kerjasama utara-utara di teras utara sulawesi. Daerah yang paling kecil wilayahnya di kawasan kerjasama adalah Kabupaten Gorontalo Utara dengan luas wilayah $1.777,22 \mathrm{~km}^{2}$ dengan tingkat kepadan 64 orang per $\mathrm{km}^{2}$. Daerah ini terletak di tengah-tengah atau diapit oleh dua daerah kerjasama utara-utara yaitu Kabupaten Buol di bagian Barat dan Kabupaten Bolaang Mongondow Utara di bagian timur.

Pertumbuhan Ekonomi Kawasan Kerjasama Utara-Utara; Perekonomian daerah di kawasan kerjasama utara-utara tumbuh dengan laju yang cukup tinggi. Dalam kurun waktu 2011-2016 tumbuh dengan rata-rata $6,74 \%$ di atas pertumbuhan ekonomi nasional. Pertumbuhan ekonomi tertinggi terjadi pada tahun 2013 sebesar 7,31\%. Secara umum pertumbuhan ekonomi tersebut digerakkan oleh sektor-sektor ekonomi pada masing-masing daerah sesuai dengan potensi yang dimiliki. Tingkat pertumbuhan ekonomi tersebut relatif stabil pada kisaran $6-7 \%$ persen per tahun dan diharapkan akan semakin meningkat dengan adanya keterbukaan dalam melakukan kerjasama yang saling membutuhkan, saling mendukung dan saling memperkuat antara sesama anggota dalam persekutuan kerjasama. Potensi untuk melakukan kerjasama sangat terbuka lebar terutama dalam peningkatan produksi serta mencari pasar bersama.

Pembentukan Produk Domestik Regional Bruto; Kontribusi Produk Domestik Regional Bruto Kabupaten Buol terhadap Produk Domestik Regional Bruto kerjasama utara-utara merupakan yang terbesar diantara anggota lainnya, dimana tahun 2016 sebesar 38,15\%. Sementara daerah yang terbesar kedua dan ketiga adalah Kabupaten Bone Bolango dan Gorontalo Utara masing-masing sebesar 27,27 \% dan 19,88 \%. Daerah yang paling kecil kontribusi Produk Domestik Regional Bruto nya adalah Kabupaten Bolaang Mongondow Utara tentunya hal ini menggambarkan sektor-sektor ekonomi di daerah ini belum terlalu berkembang.

Tingkat Kemiskinan Kawasan; Secara rata-rata tingkat kemiskinan di wilayah kerjasama utara-utara tahun 2016 sebesar $15 \%$ atau masih di atas angka rata-rata kemiskinan nasional sebesar 10,86\% pada tahun yang sama. Angka kemiskinan tertinggi dialami oleh Kabupaten Gorontalo Utara sebesar 18,51 \%, menyusul Kabupaten Bone Bolango sebesar 17,97 \%, berikut Kabupaten Buol sebesar 16,68 \% dan angka kemiskinan terkecil adalah Kabupaten Bolaang Mongondow Utara sebesar 8,35 \%. Angka kemiskinan masih menjadi masalah utama dalam setiap pelaksanaan pembangunan demikian pula di wilayah kerjasama utara-utara diharapkan melalui kerjasama antar daerah secara bertahap angka kemiskinan dapat diatasi. 


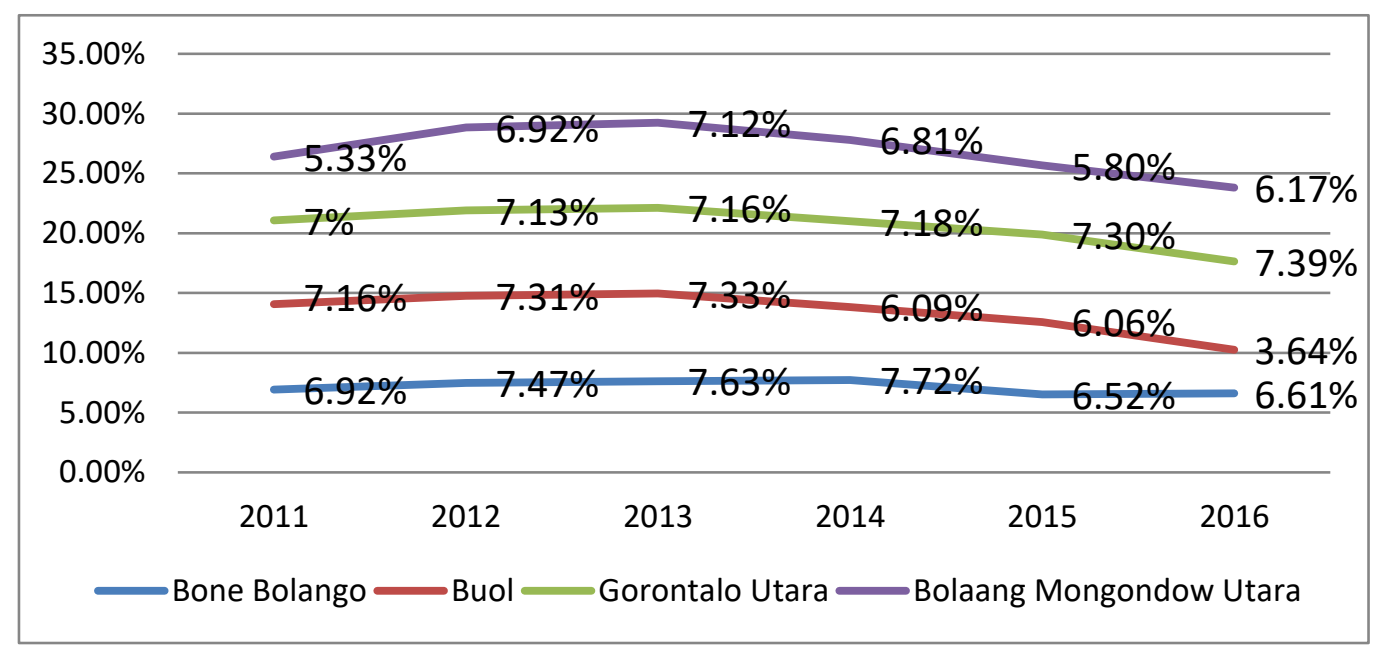

Sumber: Data di olah (2011-2016)

\section{Grafik 1.}

Pertumbuhan Ekonomi Kawasan Kerjasama Utara-Utara

Tabel 2.

Produk Domestik Regional Bruto Kawasan Kerjasama

\begin{tabular}{|c|c|c|c|c|c|c|c|}
\hline \multirow{2}{*}{ Daerah } & \multicolumn{7}{|c|}{ TAHUN } \\
\hline & 2010 & 2011 & 2012 & 2013 & 2014 & 2015 & 2016 \\
\hline Kawasan & $100.0 \%$ & $100.0 \%$ & $100.0 \%$ & $100.0 \%$ & $100.0 \%$ & $100.0 \%$ & $100.0 \%$ \\
\hline Bone Bolango & $26.59 \%$ & $26.62 \%$ & $26.67 \%$ & $26.74 \%$ & $26.96 \%$ & $26.99 \%$ & $27.27 \%$ \\
\hline Gorontalo Utara & $19.33 \%$ & $19.37 \%$ & $19.34 \%$ & $19.31 \%$ & $19.37 \%$ & $19.54 \%$ & $19.88 \%$ \\
\hline Buol & $39.1 \%$ & $39.24 \%$ & $39.26 \%$ & $39.26 \%$ & $38.98 \%$ & $38.86 \%$ & $38.15 \%$ \\
\hline $\begin{array}{c}\text { Bolaang } \\
\text { Mongondow } \\
\text { Utara }\end{array}$ & $14.98 \%$ & $14.77 \%$ & $14.73 \%$ & $14.69 \%$ & $14.69 \%$ & $14.61 \%$ & $14.7 \%$ \\
\hline
\end{tabular}

Sumber: BPS Dalam Angka Masing-Masing Kabupaten Tahun 2010-2017

Indeks Pembangunan Manusia; mengukur kondisi kehidupan sosial ekonomi suatu masyarakat. Secara rata-rata IPM dari ke empat kabupaten kawasan kerjasama utara-utara mengalami peningkatan antara tahun 2014-2016. Hal ini menggambarkan adanya perbaikan derajat kehidupan sosial ekonomi masyarakat di daerah tersebut seperti pendidikan, kesehatan dan ekonomi. Pada tahun 2016 IPM tertinggi diraih Kabupaten Bone Bolango sebesar 67,48 kemudian disusul oleh Kabupaten Buol sebesar 66,37 dan Kabupaten Bolaang Mongondow Utara sebesar 65,16 serta yang paling terkecil adalah Kabupaten Gorontalo Utara sebesar 63,03.

Produk Unggulan Badan Kerjasama Utara-Utara; Potensi alam di wilayah kerjasama utarautara sangat beragam yang tergambar dalam sektor-sektor ekonomi yang sedang dikembangkan seperti sektor pertanian, perikanan, peternakan, perkebunan, pertambangan, kehutanan, pariwisata dan 
sebagainya. Hasil penelitian (Fahrudin Zain Olilingo \& Rauf, 2017) merekomendasikan 3 komoditas unggulan yang menjadi penghela dalam pengembangan ekonomi wilayah kerjasama utara-utara (Penelitian difokuskan pada 3 kabupaten sebelum Kabupaten Bone Bolango bergabung dalam kerjasama daerah utara-utara. Perhitungan menggunakan analisis location quetiont dengan perhitungan 2 tahap yaitu tahap I mengidentifikasi sektor unggulan yang menjadi sektor basis dan tahap ke II mengidentifikasi komoditas unggulan yang bisa dikembangkan menjadi lokomotif perekonomian (Esteban-Marquillas, 1972).

Tabel 3.

Indeks Pembangunan Manusia Kawasan Kerjasama Utara-Utara Tahun 2014-2016

\begin{tabular}{llrrr}
\hline No & Kabupaten & \multicolumn{3}{c}{ IPM 2014-2016 } \\
\cline { 3 - 5 } & & $\mathbf{2 0 1 4}$ & $\mathbf{2 0 1 5}$ & $\mathbf{2 0 1 6}$ \\
\hline 1 & Bone Bolango & 66.03 & 66.83 & 67.48 \\
2 & Gorontalo Utara & 61.92 & 62.55 & 63.03 \\
3 & Bolaang Mongondow Utara & 64.24 & 64.46 & 65.16 \\
4 & Buol & 65.41 & 65.61 & 66.37 \\
\hline
\end{tabular}

Sumber : BPS Masing-Masing Kabupaten Tahun 2014-2017

Hasil perhitungan menunjukkan bahwa untuk Kabupaten Gorontalo Utara ada dua sektor ekonomi yang memperoleh nilai di atas 1 yaitu sektor pertambangan dan penggalian memperoleh 1,47 dan sektor pertanian, kehutanan dan pertambangan 1,17. Untuk Kabupaten Bolaang Mongondow Utara sama seperti Kabupaten Gorontalo Utara ada dua sektor ekonomi yang dominan yaitu sektor pertanian, kehutanan dan perikanan memperoleh nilai 2,22 dan pertambangan dan penggalian 2,16. Lain halnya dengan Kabupaten Buol ada 4 sektor ekonomi yang dominan yaitu sektor perdagangan 4,89, sektor industri pengolahan 3,37, sektor pertanian 1,39 dan sektor pertambangan dan penggalian sebesar 1,06. Atas dasar hal tersebut, maka yang menjadi sektor basis dalam pengembangan wilayah kerjasama utara-utara adalah sektor pertanian, kehutanan dan perikanan serta sektor pertambangan dengan pertimbangan: 1). Sektor pertambangan dan penggalian walaupun lokasinya berada pada ketiga kabupaten, namun saat ini kewenangan terhadap pengembangan sektor pertambangan dan penggalian sudah berada pada dinas pertambangan masing-masing provinsi dan dengan demikian program dan kebijakan sudah menjadi kewenangan provinsi. 2). Berdasarkan potensi yang dimiliki ketiga daerah ditinjau dari struktur dan letak geografis, maka sektor pertanian, kehutanan dan perikanan layak dikembangkan menjadi sektor basis. Adapun sektor perdagangan dan industri untuk saat ini akan menjadi sektor non basis yang menjadi daya dukung terhadap pengembangan potensi ke tiga daerah walaupun untuk Kabupaten Buol memperoleh nilai LQ lebih besar dari 1. Untuk jelasnya hasil identifikasi location quetiont pada ketiga daerah dapat dilihat pada tabel berikut:

Tabel 4.

Nilai LQ Rata-Rata Sektor Ekonomi Wilayah Kerjasama Utara-Utara Tahun 2010-2015

\begin{tabular}{cccccc}
\hline Kabupaten/Sektor & $\begin{array}{c}\text { Pertanian, } \\
\text { kehutanan dan } \\
\text { perikanan }\end{array}$ & $\begin{array}{c}\text { Pertambangan } \\
\text { dan penggalian }\end{array}$ & Perdagangan & $\begin{array}{c}\text { Industri } \\
\text { Pengolahan }\end{array}$ & $\begin{array}{c}\text { Jasa } \\
\text { Lainnya }\end{array}$ \\
\hline $\begin{array}{c}\text { Gorontalo Utara } \\
\text { Bolaang }\end{array}$ & 1,17 & 1,47 & 0,87 & 0,48 & 1,17 \\
Mongondow Utara & 2,22 & 2,16 & 0,83 & 0,30 & 0,43 \\
Buol & 1,39 & 1,06 & 4,89 & 3,37 & 0,96 \\
\hline
\end{tabular}

Sumber: Data diolah tahun 2017

Penguatan Daya Saing Daerah Melalui Kerjasama Teras Utara Sulawesi Indonesia Fahrudin Zain Olilingo dan I Kadek Satria Arsana 
Selanjutnya hasil identifikasi focus group discussion yang menghadirkan para camat, tokoh masyarakat serta instansi terkait pada masing-masing kabupaten menunjukkan untuk dua kabupaten yaitu Kabupaten Gorontalo Utara dan Buol sekitar $90 \%$ memilih tiga komoditas menjadi unggulan yaitu komoditas jagung dan sapi serta budidaya ikan vaname. Untuk Kabupaten Bolaang Mongondow Utara memilih komoditas sapi dan ikan kerapu menjadi komoditas unggulan. Tanaman jagung belum menjadi perioritas di daerah ini walaupun masyarakatnya ada yang sudah menanam jagung secara turun temurun. Satu komoditas lagi yang menjadi perioritas akan dikembangkan oleh ketiga daerah adalah menjajaki pengembangan budidaya udang vaname.

Ada tiga pertimbangan yang mereka sampaikan dalam pengembangan budidaya udang vaname, yaitu 1). Potensi ketiga daerah yang terletak di pinggir pantai seluas kurang lebih $300 \mathrm{~km}$ memiliki peluang untuk pengembangan udang vaname intensif apalagi tambak udang vaname sebaiknya di pinggir laut dan tidak terlalu banyak membutuhkan air tawar (Budiharsono, 2001). Udang vaname membutuhkan lebih banyak air laut yang dialirkan ke tambak sedangkan air tawar hanya berfungsi menstabilkan kadar garam (salinitas) supaya tidak terlalu tinggi. Dengan demikian letak tambak udang vaname tidak mesti dekat hulu sungai bahkan beberapa yang telah berhasil hanya mengandalkan air dari sumur suntik ataupun air PDAM. 2). Harga udang vaname cukup stabil dan mudah mendapatkan pembeli ataupun pengumpul karena jenis udang ini pasar dunia cukup terbuka. Dengan demikian para pembudidaya memiliki jaminan pasar yang pasti, apalagi pengembangan budidaya ikan vaname mendapat dukungan dari pemerintah sebagai komoditas unggulan Kementerian Perikanan dan Kelautan semenjak tahun 2001. 3). Secara teknis perawatan udang vaname relatif lebih mudah dengan jumlah pakan yang tersedia dengan harga relatif terjangkau.

Kerjasama Utara-Utara merupakan suatu bentuk kerjasama yang melibatkan daerah-daerah yang secara administratif terdiri atas beberapa daerah tingkat II yang berbeda provinsi. Menteri Pertanian Republik Indonesia Amran Suleman di Kabupaten Bone Bolango (2017) dalam pencanangan program 1 juta ekor sapi untuk kerjasama utara-utara mengatakan bahwa bentuk kerjasama ini merupakan yang unik karena belum pernah terjadi di daerah lainnya di Indonesia. Menyatukan daerah yang berbeda wilayah administratif bukanlah pekerjaan yang mudah apalagi memiliki karakteristik kultur, budaya yang berbeda sehingga terkadang muncul egoisme daerah yang sering meretakkan hubungan kerjasama.

Secara teoritis daerah yang berdekatan namun dibedakan oleh latar belakang administratif, kultural dan historis bisa disatukan oleh kepentingan yang sama sehingga membentuk suatu Wilayah Nodal (Budiharsono, 1989). Keempat Kabupaten dengan difasilitasi Universitas Negeri Gorontalo telah sepakat untuk membentuk suatu kesepakatan kerjasama merupakan modal utama yang terus harus dijaga untuk mencapai keunggulan daya saing bersama dalam mencapai kesejahteraan masyarakatnya. Hal ini sejalan dengan hasil Penelitian yang dilakukan oleh (Husna et al., 2013) di Kabupaten Gresik bahwa untuk meningkatkan daya saing daerah selain mengembangkan sektor-sektor unggulan penting juga daerah mengoptimalkan kerjasama antar daerah disekitarnya, sebab sangat menguntungkan untuk daerah dalam pembangunan perekonomian bersama. Secara teori penguatan daya saing daerah dipengaruhi oleh beberapa faktor seperti keputusan politik dan proses politik. Kedua faktor tersebut sejatinya menghendaki bargaining position, (Imawan, 2002). Untuk itu maka komitmen ini harus diwujudkan dalam perspektif bahwa kerjasama ini mendatangkan manfaat bagi semua anggota yang terlibat yang saling menguntungkan, saling memperkuat dan saling mendukung.

Ada beberapa upaya penting yang harus dilakukan dalam pembenahan daya saing daerah kerjasama utara-utara, yaitu: Menjaga komitmen bersama dalam mempertahankan momentum kerjasama; Badan Kerjasama Utara-Utara perlu menjaga momentum pertumbuhan ekonomi yang saat ini secara rata-rata di atas pertumbuhan ekonomi nasional. Upaya yang harus dilakukan adalah selain menjaga stabilitas ekonomi makro masing-masing daerah, juga perlunya ditumbuhkan kesadaran dan perasaan memiliki wadah kerjasama utara-utara sebagai wadah bersama dalam memperjuangkan pengembangan ekonomi daerah dalam menciptakan daya saing dan pertumbuhan ekonomi kawasan. Untuk itu perlu dikedepankan pembagian peran masing-masing daerah sesuai potensi yang dimiliki sehingga tidak saling mematikan antara daerah yang satu dengan daerah lainnya.

Peningkatan peran masyarakat dalam kerjasama utara-utara; Forum dialog antara pemerintah dan dunia usaha perlu terus digiatkan untuk menumbuhkan pemahaman arti pentingnya kerjasama utara-utara bagi 
masyarakat. Komunikasi dan koordinasi amat penting dalam pengelolaan potensi ekonomi dengan mengedepankan visi yang sama ke dalam harus selalu membagi peran dan keluar harus menyatu dalam menciptakan daya saing bersama.

Perbaikan iklim usaha dan iklim usaha daerah; Pemerintah daerah dan pemangku kepentingan daerah lainnya secara bersama-sama perlu meningkatkan iklim investasi dan iklim usaha agar daerahnya dapat menjadi tempat berinvestasi yang lebih menarik, aman dan kondusif. Hal ini dipandang penting karena peningkatan investasi akan menciptakan lapangan pekerjaan sehingga dapat mengurangi pengangguran dan tentunya akan berdampak pada pengurangan angka kemiskinan. Untuk itu upaya strategis yang perlu dilakukan adalah: (i) Mempermudah pelayanan perizinan usaha, (ii) Meningkatkan transparansi proses dan biaya perizinan, serta (iii) Menghapuskan berbagai regulasi/ peraturan daerah yang tumpang tindih dan yang terlalu membatasi dunia usaha untuk berkembang.

Peningkatan Infrastruktur Daerah; Infrastruktur memegang peranan penting dalam mempercepat konektivitas, aksesibilitas antar daerah dalam pelaksanaan pembangunan. Infrastruktur tersebut juga sangat dibutuhkan dalam proses pengelolaan potensi misalnya jalan akses ke lokasi produksi, pelabuhan, telekomunikasi dan energi, serta sarana air minum. Pemerintah daerah pada ke empat daerah harus mempersiapkan hal ini dalam kerangka kerjasama utara-utara untuk peningkatan daya saing dalam menarik investor.

Peningkatan daya saing produk ekspor unggulan daerah; Pasar ekspor memegang peranan penting dalam memacu produk dalam daerah dan tentunya akan berdampak pada peningkatan pendapatan masyarakat serta menjadi sumber pendapatan asli daerah. Masing-masing daerah di wilayah kerjasama utara-utara memiliki potensi produk yang dikembangkan menjadi barang ekspor. Dari data yang dipublikasi oleh Badan Pusat Statisik terlihat bahwa ekspor barang dagangan dari ke empat daerah kerjasama utara-utara belum terlalu berkembang, untuk itu hal ini perlu menjadi program bersama dalam menorobos pasar ekspor baik di kawasan ASEAN maupun pasar Eropah dan negara lainnya.

Peningkatan kualitas Sumber Daya Manusia daerah; Sumber Daya Manusia yang dibutuhkan dalam proses pembangunan terdiri atas dua jenis yaitu tenaga kerja terampil yang memiliki pengetahuan manejerial dan penguasaan Iptek serta tenaga kerja lapangan. Oleh karena itu, Pemerintah Daerah perlu merumuskan kebijakan dan upaya strategis untuk meningkatkan kualitas SDM di daerahnya. Beberapa hal penting perlu dilakukan antara lain adalah: (i). Membangun kerjasama dengan perguruan tinggi terutama dalam penyiapan tenaga kerja terampil yang memiliki pengetahuan Iptek dan manajerial (ii). Meningkatkan peran Balai Pelatihan Tenaga Kerja untuk menyiapkan serta meningkatkan kemampuan tenaga kerja sesuai kebutuhan tenaga kerja di lapangan (iii). Peningkatan kerjasama dengan daerah lainnya terutama dalam kerjasama magang tenaga kerja dan studi banding.

Penciptaan iklim ketenagakerjaan daerah yang lebih kondusif; Penciptaan iklim yang kondusif bagi ketenagakerjaan dimaksudkan agar tenaga kerja memiliki rasa memiliki (sense of belonging) terhadap tempat dia bekerja. Hal ini penting karena konsistensi tenaga kerja dalam bekerja mengakibatkan kestabilan kerja dan juga berakibat dalam kestabilan perusahaan karena tenaga kerja menganggap tempatnya bekerja adalah rumahnya yang perlu dijaga. Untuk itu ada beberapa hal yang perlu diperhatikan daerah adalah (i). Selalu menyesuaikan upah minimum kabupaten agar sesuai laju inflasi tetapi tidak memberatkan dunia usaha (ii). Mendorong komunikasi bipartit yang lebih baik antara pengusaha dan pekerja, terutama dalam penentuan upah dan penyelesaian permasalahan perburuan lainnya (iv). Memberikan edukasi kepada asosiasi/serikat buruh di daerah untuk menjaga iklim ketenagakerjaan yang lebih baik dan menghindari gerakan buruh yang bersifat radikal dan anarkis.

Tarigan (2009) dalam tulisannya mengenai kerjasama antar daerah untuk peningkatan penyelenggaraan pelayanan publik dan daya saing wilayah menjelaskan bahwa peningkatan daya saing daerah melalui kerjasama antar daerah memiliki peranan yang mampu meningkatkan keunggulan komparatif dan kompetitif daerah. Sebab dengan adanya kerjasama daerah mampu meningkatkan efektivitas dalam pengelolaan sumber daya, meningkatkan investasi lokal maupun asing melalui pemasaran dan promosi daerah secara bersama-sama dalam lingkup kerjasama. Kerjasama 
daerah memang sangat menguntungkan karena dengan adanya kerjasama, daerah-daerah yang melaksanakan kerjasama akan lebih dipermudah dalam membangun sebuah perekonomian. Sebab kerjasama pada prinsipnya adalah saling menguntungkan. Namun, terdapat hal yang lebih penting dalam membangun kerjasama daerah yakni komitmen. Komitmen dalam kerjasama sangat dibutuhkan, karena dengan demikian tujuan dari kerjasama akan dapat dicapai apabila komitmen dari awal sampai akhir terus ditingkatkan.

\section{SIMPULAN DAN SARAN}

Badan Kerjasama Utara-Utara (BKSU) merupakan organisasi yang unik karena baru pertama kali di Indonesia suatu organisasi yang menyatukan 4 daerah dari 3 provinsi serta melibatkan universitas sebagai fasilitator. BKSU memiliki visi menjadi lumbung pangan dan energi di Indonesia Timur sehingga akan membentuk suatu pertumbuhan ekonomi baru di kawasan utara sulawesi. BKSU memiliki potensi yang sangat beragam dalam berbagai sektor seperti sektor pertanian, peternakan, perkebunan, perikanan, pariwisata, kehutanan dan pertambangan sehingga dalam pengelolaannya membutuhkan kerjasama yang saling membutuhkan, saling memperkuat, dan saling mendukung. Pertumbuhan ekonomi kawasan kerjasama di atas rata-rata angka pertumbuhan ekonomi nasional menunjukkan besarnya potensi ekonomi kawasan ini dan diharapkan akan semakin kuat dengan adanya kerjasama kawasan (utara-utara). Namun demikian, kerjasama utara-utara masih perlu bekerja keras untuk menyusun upaya-upaya yang terintegrasi agar sasarannya akan terwujud dan akan memberikan manfaat yang optimal bagi perekonomian Indonesia. Hal ini karena masih kurangnya infrastruktur pendukung ekonomi, belum terintegrasinya perencanaan karena masih dipengaruhi oleh visi masing-masing daerah sehingga mempengaruhi pencapaian visi bersama.

Untuk itu, seluruh pemangku kepentingan perlu bersama-sama meningkatkan komitmen, kesiapan dan menyatukan langkah dalam penyampaian visi terutama tetap konsisten menumbuhkan rasa memiliki (sense of belonging) dikalangan para anggotanya. Makalah ini merekomendasikan perlunya penguatan daya saing masing-masing daerah niscaya akan menjadi daya saing bagi daerah kawasan kerjasama utara-utara. Selain itu, berharap penelitian ini memberikan sumbangsih pemikiran serta rujukan dalam pengembangan ilmu pengatahuan khususnya peningkatan daya saing daerah melalui kerjasama daerah.

\section{REFERENSI}

Agostinho, S. (2005). Naturalistic inquiry in e-learning research. International Journal of Qualitative Methods, $4(1), 13-26$.

Bagaskara, A. M., \& Pattipelohy, S. C. (2018). Kerjasama Pemerintah Indonesia dan ECPAT dalam Menangani Permasalahan Child Trafficking di Indonesia. Journal of International Relations, 4(3), 367-375.

Basco, R. (2015). Family business and regional development-A theoretical model of regional familiness. Journal of Family Business Strategy, 6(4), 259-271.

Budiharsono, S. (1989). Perencanaan Pembangunan Wilayah: Teori, Model Perencanaan dan Penerapannya. Bappenas, Jakarta.

Budiharsono, S. (2001). Teknik analisis pembangunan wilayah pesisir dan lautan. Pradnya Paramita.

Esteban-Marquillas, J. M. (1972). I. A reinterpretation of shift-share analysis. Regional and Urban Economics, 2(3), 249-255. 
Golafshani, N. (2003). Understanding reliability and validity in qualitative research. The Qualitative Report, $8(4), 597-607$.

Husna, N., Noor, I., \& Rozikin, M. (2013). Analisis Pengembangan Potensi Ekonomi Lokal Untuk Menguatkan Daya Saing Daerah Di Kabupaten Gresik. Jurnal Administrasi Publik, 1(1), 188-196.

Imawan, R. (2002). Peningkatan Daya Saing: Pendekatan Paradigmatik-Politis. Jurnal Ilmu Sosial Dan Ilmu Politik, 6(1), 79-104.

Martynova, E. S. (2014). Strengthening of Cooperation Between R ussia and ASEAN: Rhetoric or Reality? Asian Politics \& Policy, 6(3), 397-412.

Mudrajad, K. (1997). Ekonomi Pembangunan: Teori, Masalah dan Kebijakan. Sleman: Unit Penerbit Dan Percetakan, Akademi Manajemen Perusahaan YKPN.

Olilingo, Fachrudin Zain. (2014). Analisis Potensi Dan Pemanfaatan Lahan API dan HGU Dalam Pengembangan Investasi. Penelitian Mandiri, 1(1051).

Olilingo, Fahrudin Zain, \& Rauf, A. (2017). Analisis Sektor Unggulan Wilayah Kerjasama Utara-Utara Sulawesi. Repository.Ung.Ac.Id.

Park, Y.-J. (2017). Strengthening ASEAN 3 Regional Financial Arrangements: A New Framework Beyond CMIM. East Asian Economic Review, 21(1), 59-80.

Saneev, B., Sokolov, A., Lagerev, A., Popov, S., Ivanova, I., Izbuldin, A., Korneyev, A., Muzychuk, S., \& Sokolov, D. (2018). A shift in the paradigm of energy cooperation between Russia and Northeast Asia countries facing new global and regional challenges: from predominant sale of energy resources to innovation and technology cooperation. E3S Web of Conferences, 27, 2001.

Sun, Y. (2016). The structure and dynamics of intra-and inter-regional research collaborative networks: The case of China (1985-2008). Technological Forecasting and Social Change, 108(2), 70-82.

Tarigan, A. (2009). Kerjasama Antar Daerah (KAD) untuk Peningkatan Penyelenggaraan Pelayanan Publik dan Daya Saing Wilayah. Bulletin Online Tata Ruang Maret 2009 Badan Perencanaan Dan Pembangunan Nasional.

Tilzey, M. (2017). Reintegrating economy, society, and environment for cooperative futures: Polanyi, Marx, and food sovereignty. Journal of Rural Studies, 53(1), 317-334.

Utomo, T. W. W. (2006). Prospek Pengembangan Kerjasama Antar Daerah Kabupaten/Kota di Kalimantan Timur Dalam Penyelenggaraan Urusan Pembangunan dan Pelayanan Masyarakat. Jurnal Borneo Administrator, 2(1).

Zakharova, L. (2016). Economic cooperation between Russia and North Korea: New goals and new approaches. Journal of Eurasian Studies, 7(2), 151-161. 